\title{
Human Rights and Sporting Contact: New Zealand Attitudes to Race Relations in South Africa, 1921-94.
}

\author{
Reviewed by Chris Laidlaw
}

Human Rights and Sporting Contact: New Zealand Attitudes to Race Relations in South Africa, 1921-94.

Malcolm Templeton.

Auckland: Auckland University Press, 1998.

It was always expected that sooner or later someone would write the definitive book on the sorry business of New Zealand's sporting contacts with South Africa. It's been a long wait however, largely due to the want of objectivity among those closest to the action and a certain diffidence about raking over the ashes among some of the personalities involved.

Malcolm Templeton's survey, Human Rights and Race Relations, suffers neither from diffidence nor from subjectivity. Even though the author, a highly respected Foreign Affairs official, makes little secret as to which side he was on during the hotter years, this is a work which sticks faithfully to the facts. And it is all the more admirable for it. Templeton's perspective was, understandably, a governmental one and the story is revealed through the lens of officialdom.

Templeton has taken the period 1921 to 1994 as his tableau and he meticulously traces each development of significance-the politics, the diplomacy and the sport itself-and puts it into context. For a serious historical analysis it makes a remarkably good read. It reveals, like the removal of onion layers, the depths to which the issue of discrimination in South Africa came to pollute relationships in this country, and between this country and many others. It lays bare the catalogue of lies, deception, dirty tricks and duplicity that successive South African governments were prepared to indulge in to preserve the sporting lifeline with the outside world.

New Zealand became the focus of much of that effort in the 1970s and 80s and the issue began to tear us apart politically and emotionally. Templeton brings to life the agonies visited on individuals like Walter Nash, Norman Kirk, Muldoon and Lange as they wrestled with their consciences to varying degrees in coming to terms with the highly combustible electoral implications of the issue of apartheid. Recitation of the facts have a way of revealing heroes and villains and Templeton has let the facts of Robert Muldoon's 
leading part in the whole business speak for themselves. They tell a particularly unpleasant tale and it is important that the factors that motivated Muldoon to thwart any pro-activity on New Zealand's part during his time as Prime Minister should be publicly revealed.

Muldoon is not the only individual to have the blowtorch of historical fact turned on him. Others like Jack Marshall who set out to 'build bridges' with South Africa are seen in the cold light of hindsight to have tragically misread the potential for domestic trouble that this corrosive issue promised for New Zealand.

Templeton also reveals the extraordinarily narrow focus of New Zealand's diplomacy in the post-war years; the concentration on clinging to the apron strings of Britain and the 'old' Commonwealth; the open distrust of non-white aspirations beyond the Anglo-saxon fold, and the blindness of so many in this country to the massive tragedy that was unfolding in South Africa after Daniel Malan and the Afrikaner Nationalists seized the initiative in 1949.

Although the author lays this out unburdened by subjective comment, his comprehension of the issues, arrived at first hand, means that every now and again he cannot resist a subtle dig at whoever is in focus.

Rugby of course features very prominently in the whole story. It is the lever by which the South African Government and Rugby Union kept New Zealand jumping. It was worked with consummate skill. The South African Consuls General in New Zealand followed to the letter the old dictum that a diplomat is an honest man sent abroad to lie for his country. They raised this particular vocation to an art form in New Zealand and succeeded in fooling most of the people most of the time for much too long. Templeton is a good deal kinder to the leading lights of the New Zealand Rugby Union and the pro-tour lobby than some others of us would be inclined to be. He lays out the case, made ad nauseum by the NZRU that politics and sport could somehow be kept apart, without seriously questioning the integrity of anybody. Yet the facts show pretty clearly that there were plenty of people, including more than a few in the upper echelons of the Rugby Union, who were totally in favour of apartheid and wanted to maintain the purity of white man against white man right up until the mid 1980s.

In his 'few reflections' at the end of the book Templeton looks back on the strain that the issue put on relations between officials and politicians in New Zealand and the huge preoccupation with it that diverted so many people for so long. He wonders, at the end, if we are really cured of the kind of prejudice that gave rise to the conflict. If we aren't then this book should be required reading for all those who still carry that prejudice. What a pity it will only be read by those who don't. 
Chris Laidlaw

Wellington

Kōtare 2, no. 1 (1999), pp. 74-76. 